\title{
INDIVIDUAL STUDENT WORKS AS A WAY TO INCREASE INTEREST IN TECHNICAL DISCIPLINES AND SCIENCE
}

\author{
Jana KALOVÁ
}

\begin{abstract}
Paper responses to current and frequently mentioned problem of lack of students' interest to study technical fields. Goal of the paper is to introduce examples of specific activities and results of grammar school students. These results significantly exceed a scope of a standard curriculum and head students to prefer science and technical subjects. Several student works are presented.
\end{abstract}

Key words: science and technical subjects at school, individual work of student, competition.

\section{SAMOSTATNÉ STUDENTSKÉ PRÁCE JAKO PROSTŘEDEK PRO ZVÝŠENÍ ZÁJMU O TECHNICKÉ A PŘÍRODOVĚDNÉ OBORY}

Resumé: Příspěvek reaguje na aktuální a často zmiňovaný problém, kterým je nezájem studentů o studium technických oborů. Cílem př́spěvku je uvedení prríkladů konkrétních činností a výsledků studentů všeobecného gymnázia, které značně přesahují rámec standardního učiva, a které směrují studenty $\mathrm{k}$ preferenci prírodovědných a technických oborů. Jsou uvedeny ukázky několika studentských prací.

Klićčová slova: přírodovědné a technické předměty ve škole, samostatné práce studentů, soutěž.

\section{1 Úvod}

Všeobecně známým, aktuálním a často diskutovaným problémem ve vyspělých zemích je menší zájem žáků základních škol a středoškolských studentů o př́rodovědné a technické obory ve srovnání s obory ekonomickými či humanitními $[1,2]$.

Existuje celá řada studií, ve kterých specialisté $\mathrm{z}$ nejrůznějších oborů analyzují příčiny tohoto stavu. Ekonomové studují vliv pobídek, napríklad výše platů, na získání a udržení kvalitních učitelů $[3,4]$. Pedagogové zase zkoumají, jak měřit a definovat kvalitu učitele [5-8].

Cílem předkládaného př́íspěvku není shrnutí př́čin zmíněných jevů ani analýza jejich společenských dopadů, spíše článek seznamuje a informuje čtenáŕe s konkrétními projekty, které souvisejí s popisovanou problematikou a které byly realizovány $\mathrm{v}$ průběhu několika let na jednom českobudějovickém gymnáziu. Na těchto projektech lze ukázat možný př́stup podpory studentů v prrírodovědných a technických oborech.

Specifikem Gymnázia Jírovcova v Českých Budějovicích je vzdělávání podle učebního plánu $\mathrm{s}$ rozšiřrenou výukou př́rodovědných předmětů, matematiky a informatiky, které probíhá vždy $\mathrm{v}$ jedné ze tříd každého ročníku čtyřletého gymnázia. Výuka v těchto speciálních třídách je nabízena od školního roku 1999/2000 náhradou za dřívější matematické třídy (zaměření 01).

Kromě v mnohých směrech nadstandardního obsahu povinné výuky, je do vzdělávání zařazena nepovinná př́prava studentů na předmětové soutěže, v nichž dosahují prestižních výsledků v regionálním, celostátním i mezinárodním srovnání. Studenti zmíněného gymnázia získávají významná ocenění v mezinárodní olympiádě astronomické, biologické, ekologické, fyzikální, chemické, matematické i v ostatních soutěžích.

Stručný přehled úspěchů lze nalézt např. na webových stránkách gymnázia nebo v publikacích $[9,10]$.

Dále jsou studentům zadávány samostatné práce. Jejich témata jsou volena podle schopností a zájmu studentů, podle jejich snahy a ochoty pracovat na sobě. Pokud je student v některém předmětu $\mathrm{v}$ předstihu před spolužáky, pak může samostatně na svém tématu pracovat i při vyučování.

Talentovaným, pracovitým nebo úspěšným studentům jsou poskytovány i další možnosti pro jejich rozvoj. Se svými pracemi se zúčastňují různých soustředění a soutěží. Předávání takto získaných zkušeností spolužákům je pak neocenitelné. Být úspěšný na celostátní či mezinárodní úrovni $\mathrm{v}$ nějaké předmětové olympiádě dokáže i přes důkladnou přípravu jen málokdo. Vytvořit kvalitní samostatnou práci však může každý, kdo má nějaký konkrétní cíl 
zájmu a je dostatečně pracovitý a vytrvalý (což samozřejmě bývá problém a velmi výraznou roli $\mathrm{v}$ takových př́ípadech zastává důslednost učitele).

\section{Samostatné práce studentů}

Autorka článku v průběhu několika let na Gymnáziu Jírovcova zadávala, vedla či konzultovala velký počet studentských prací [9,11]. Získané zkušenosti potvrzují, že $\mathrm{k}$ vytvoření úspěšné práce vede náročná cesta. Velmi důležitým krokem je vhodný výběr tématu $\mathrm{v}$ součinnosti studenta a učitele. V několika př́padech byl zprostředkován kontakt studenta s odborným konzultantem z vysokoškolského pracoviště. Konzultace se studenty probíhají různými formami - př́mým kontaktem, přes e-mail nebo Skype.

V mnoha př́padech následuje po ukončení práce účast na soutěžích a přehlídkách. Pozitivní účinek takových př́ležitostí je evidentní. Někdy však mají přehlídky také antimotivační vliv. Jestliže už student pracuje nad rámec povinností, pak ve většině př́padů rád svou práci předvede. Je-li někam pozván, a pak o něho není zájem (stačí, že přijel), může ho taková situace odradit, a dřina, kterou vynaložil on, jeho učitel a školitel, je znehodnocena.

Vynikající je ovšem zapojení studentů prímo do výuky. Autor prezentuje dílčí nebo souhrnné výsledky své práce při vyučování před spolužáky $\mathrm{z}$ jiných tříd i $\mathrm{z}$ jiných středních škol. Motivace dalších studentů takovým způsobem je mimořádná. Nejde přitom jen o zvýšení nebo vyvolání zájmu o vlastní tvorbu samostatné práce. Po takových vystoupeních je pozorováno také zvýšení aktivity studentů při dalších hodinách.

\section{Ukázky studentských prací}

V roce 2006 byla vytvořena úspěšná práce s názvem Hustá rozmístění (autor Tomáš Trnka, odborný konzultant Mgr. Radek Výrut, KMA FAV ZČU v Plzni).

Úryvek $\mathrm{z}$ anotace práce:

Tématem práce je řešeni tzv. „containment problem " neboli nalezeni minimálniho kontejneru pro daný mnohoúhelnik, kde minimálnim kontejnerem rozumime opsaný obdélník s co nejmenšim obsahem. Tento problém má široké praktické aplikace, kupř́kladu právě při tvorbě tzv. „,hustých rozmistěni", kdy je potřeba dané mnohoúhelníky co nejefektivněji poskládat do určeného prostoru (tyto mnohoúhelniky mohou být určitými součástkami, které je třeba vysekat z plechu)......Cílem práce bylo navrženi algoritmu, který by tento problém $\check{r}$ rešil, a dále jeho prevedení do praxe napsáním spustitelného počitačového programu (využit byl jazyk $\mathrm{C}++$ na platformě MS Windows)... Implementovaný algoritmus by bylo možno ihned využit v praxi.

Práce byla oceněna druhým místem $\mathrm{v}$ krajském kole SOČ v oboru Matematika a matematická informatika. Nejvýznamnějším úspěchem studenta byl však zisk stř́brné medaile a reprezentace České republiky v 38. ročníku Mezinárodní chemické olympiády v jihokorejském Gyeongsanu. Chemii si student dále velmi úspěšně věnuje při svém vysokoškolském studiu.

V roce 2007 vznikla velmi úspěšná práce Grameen bank - Microcredit for the poor (autor Adam Kabela, odborný konzultant RNDr. Petr Stehlík, KMA FAV ZČU v Plzni).

Úryvek $\mathrm{z}$ anotace práce:

V roce 2006 dostal Nobelovu cenu za mír Muhammad Yonus za systém půjčování peněz chudým lidem v Bangladéši. Bangladéšská Grameen Bank je vzorem pro několik dalšich bank v chudých zemich Asie i jinde ve svètě..... Cílem práce je ukázat, jak tyto úvěry fungují a pomoci matematické teorie her vysvètlit základni principy, díky kterým je Microcredit for the poor úspěsný. Pomoci teorie her namodelovat chováni klientů vůči bance a chováni banky ke klientưm. Popsat vzájemné chování klientù ve skupině. Ukázat, proč si může Grameen Bank dovolit tak na prvni pohled vstrícný prístup ke klientům. A zároven vysvětlit některé zajímavé jevy, které jsou sfungováním banky spojené (převaha žen mezi dlužniky, nebo nadprüměrný podil splacených úvěrů...)

Práce Adama Kabely byla oceněna prvním místem $v$ krajském kole a třetím místem $\mathrm{v}$ národním kole SOČ $\mathrm{v}$ oboru Ekonomika a ř́zení, třetím místem a cenou Mu Alpha Theta Award v národním kole soutěže Amavet Expo Science 2007 a postupem na mezinárodní výstavu vědeckotechnických projektů (Jihoafrická republika). Student po maturitě na gymnáziu nastoupil ke studiu na katedru matematiky FAV ZČU v Plzni, kde v loňském roce úspěšně ukončil magisterské studium.

V roce 2008 zaznamenala úspěch práce Korelační analýza a její aplikace při hledání modelu podchlazené vody (autoři Matyáš Kopp, Kryštof Měkuta, konzultant Jana Kalová).

Úryvek z anotace práce:

V praktické části jsme se pokusili najit vhodný regresni model závislosti hustoty podchlazené 
vody na její teplotě při atmosférickém tlaku. Zkoumání tohoto jevu má zásadni vliv prì zkoumáni globálního oteplování. Podchlazená voda se také vyskytuje v mracich nad póly, kde se zkoumá její vliv vchemických reakcich ovlivňujicích tvorbu ozónu. Pro popis termodynamických vlastností vody a vodní páry existuje mezinárodní rovnice IAPWS. Pro oblast podchlazené vody se z této rovnice vlastnosti podchlazené vody vypočítávaji extrapolací. Práce s touto rovnici je díky velkému množstvi koeficientů složitá. Sestavili jsme vlastní funkčni závislost pro výpočet hustoty pro metastabilni oblast vody.

Práce byla oceněna 1 . místem v krajském kole SOČ. Studenti prezentovali svou práci na přehlídce Expo - Sciences Europe 2008 v Budapešti. Dále za výjimečné vědecké aktivity $\mathrm{v}$ př́rodovědných oborech získali prestižní cenu Učené společnosti České republiky v kategorii Středoškolský student. [12]. Autoři práce si pro svá vysokoškolská studia zvolili technické obory a informatiku.

Ve školním roce 2011/2012 vznikla vynikající samostatná studentská práce PROTEUS Multifunkční zařízení pro vývoj a servis elektroniky na bázi mikrokontrolerů PIC (autor Marek Novák, konzultant Jana Kalová, oponent Ing. Michal Šerý, Katedra aplikované fyziky a techniky, JČU v Českých Budějovicích).

Úryvek $\mathrm{z}$ anotace práce:

Práce na projektu PROTEUS méla za cíl navrhnout a prakticky realizovat zařizení, které $v$ sobě bude zahrnovat funkcionalitu vice jednoúčelových měřidel. Výsledku bylo dosaženo použitím několika mikrokontroleru PIC18F, které spolu komunikují a vzájemně spolupracují. Větši počet prídavných a podpuirných modulü si vyžádal i poněkud netradični konstrukční rešeni $v$ podobě sběrnicového systému. Tento systém vyv programu rešil nejen rozvod napájení a signálü, ale $i$ mechanické upnutí spojových desek modulù. Ovládáni celého prìstroje, všech jeho funkcí, je ř řšeno výlučně přes 5,2palcový dotykový grafický displej o rozlišeni 240x128 pixelü. Zařizeni je konstrukčně řšeno stavebnicově, umožňuje postupnou realizaci $i$ využivání. Součásti tohoto zařizení je i software, který umožňuje posiláni screenů do PC přes USB port a jejich zobrazení, např. na projekčním plátnè.

Student zvítězil v celostátním kole SOČ v oboru elektrotechnika, elektronika a telekomunikace, kde navíc získal cenu Talent roku 2012, širší nominace na zahraniční soutěže,
Cenu MŠMT, Cenu Středočeského kraje nebo Cenu ředitele útvaru centrální inženýring JE Temelín. V říjnu 2012 získal Marek Novák za tento projekt prestižní cenu Česká hlavička 2012 v kategorii Ingenium. V květnu 2013 bude reprezentovat Českou republiku na soutěži Intel ISEF 2013 v USA. Student v současné době pravidelně publikuje v Amatérském Radiu a pracuje na vývoji menších zařízení s mikrokontrolery. Po maturitě zcela jistě bude volit pro svá další studia technicky zaměřenou vysokou školu.

Fakulta strojní ZČU v Plzni připravila ve školním roce 2011/12 soutěž pro středoškoláky s názvem Postav vozítko na elektrický pohon [13]. V kategorii Model bylo úkolem vytvořit funkční model vozítka na elektrický pohon s jasným určením prvků elektrického pohonu, zdrojů energie a doplňků. Vítězství v této kategorii získal s modelem Easypark tým Gymnázia Jírovcova (autoři modelu Petr Houška, Michal Chamra, Jan Mach, Martin Šerý, vedení týmu Jana Kalová). V následujícím školním roce si studenti jako povinně volitelné předměty zvolili matematiku, fyziku a informatiku. Technickým či prŕrodovědným předmětům se budou po složení maturitní zkoušky věnovat na vysokých školách.

Za zmínku stojí, že MŠMT ČR prostředním programu Excelence [14] ocenilo v posledních dvou letech školy, které se věnují podpoře talentovaných studentů s důrazem na technické a přírodovědné obory, významnými finančními částkami. Tato finanční podpora je určena pedagogům, kteří se studentům $\mathrm{v}$ této oblasti věnují a má silný motivační účinek.

\section{Podpora ze zahraničí}

Evropský vzdělávací systém je spíše než na péči o elity a talenty postaven na rovnostářství. Naproti tomu V USA byla $\mathrm{v} 70$. letech zrrízena federální Rada pro výjimečné děti (CEC, Council for Exceptional Children) [15] a byl vypracován systém finanční podpory nadaných studentů. Americký systém tak poskytuje ve větší míře podporu a pomoc nadaným dětem a jejich učitelům [16].

Několik desítek středoškoláků z České republiky získalo vynikající možnost zúčastnit se dlouhodobých on-line kurzů Centra pro talentovanou mládež (Center for Talented Youth - CTY) při americké univerzitě Johna Hopkinse v Baltimore [17]. Některé z kurzů jsou zakončeny zkouškou uznávanou na zahraničních vysokých školách. Iniciátorem a sponzorem 
programu pro české a slovenské studenty je American Fund for Czech and Slovak Leadership Studies (AFCSLS) a vybraní studenti z České republiky mají tak zatím možnost absolvovat zdarma kurzy pod vedením amerických lektorů a stínových instruktorů z České republiky. Studenti Gymnázia Jírovcova si zvolili např. kurzy matematiky, fyziky, chemie, biologie či informatiky.

\section{Závěr}

Ve vyšších ročnících se prohlubují rozdíly mezi špičkami třídy a ostatními studenty. Individuální př́stup ke studentům je nezbytností. Často je třeba mít několik úrovní prríprav na jednu vyučovací hodinu, včetně námětů pro samostatné práce. Pro učitele je samozřejmě taková práce velice náročná - jak v přípravné fázi, tak př́mo při výuce. Ale většinou studenti takový př́stup ocení, což se potom projeví v jejich výkonech a výsledcích.

Vynikajícím výsledkem vzdělávání je rozhodně každý úspěšný pokus pedagoga o zvýšení motivace studentů, nasměrování jejich profesní orientace, pomoc při výběru vhodných volitelných předmětů, to vše za plného respektování individuality studenta.

Činnosti popisované $\mathrm{v}$ předkládaném článku mohou sloužit jako prríklad dobré praxe [18].

\section{Literatura}

[1] SJÖBERG, S. Science and Technology in Education - Current Challenges and Possible Solutions, Invited contribution to Meeting of European Ministers of Education and Research, Uppsala 1-3 march 2001, (on-line) Dostupné z: http://www.iuma.ulpgc.es/ nunez/sjobergreports ciencetech.pdf [version 21. februar 2001]

[2] WELlS, B. H., SANCHEZ, H. A., ATTRIDGE, J.M. Modeling Student Interest in Science, Technology, Engineering and Mathematics , 2007 IEEE Meeting the Growing Demand for Engineers and Their Educators 2010-2020 International Summit, Munich, Germany, 9-11 Nov. 2007. ISBN 978-1-42441916-6.

[3] MILANOWSKI, A. An exploration of the pay levels needed to attract students with mathematics, science and technology skills to a career in K-12 teaching, Education Policy Analysis Archives, 11(50), December 27, 2003.

[4] PODGURSKY, M. Is Teacher Pay "Adequate?", JFK School of Government, Harvard University, October 2005.
[5] GOLDHABER, D. The Mystery of Good Teaching, Education Next, Spring 2002.

[6] HANUSHEK, E. Teacher Quality, Teacher Quality, edited by Lance Izumi and Williamson Evers, Hoover Institute Press, 2002.

[7] KOPPICH, J. All Teachers are not the same, Education Next, Winter 2005.

[8] HANUSHEK, E. Some Simple Analytics of School Quality, NBER Working Paper 10229, January 2004.

[9] KALOVÁ, J. Studentská odborná činnost na Gymnáziu Jírovcova, Sbornik př́spěvků 3. konference Užití počitačů ve výuce matematiky, České Budějovice, 2007. ISBN 978-80-7394048-5.

[10] Almanach 40 let od založeni Gymnázia Jirovcova, vydáno v roce 2011.

[11] KALOVÁ, J. Podpora talentovaných studentů, Pracovní seminár $k$ problematice zvyšováni zájmu žáků a studentů o prírodovédné obory, ZČU Plzeň, 2007. ISBN 978-80-7043622-6.

[12] Cesta k vědě vede přes dobrou střední školu, akademický bulletin, Oficiální časopis Akademie věd $\check{C} R$, červen 2008. (on-line) [cit. 27.6.2008] Dostupné z:

http://abicko.avcr.cz/2008/6/03/cesta-k-vedevede-pres-dobrou-stredni-skolu.html.

[13] Elektromobilita na FST ZČU, 2012. Dostupné z:

http://www.elektromobilita.zcu.cz/soutez.html

[14] Program Excelence středních škol, (on-line) [cit. 23.1.2013]. Dostupné z :

http://www.msmt.cz/pro-novinare/ministerstvoskolstvi-loni-prostrednictvim-programu [15] Council for Exceptional Children (on-line). Dostupné z: http://www.cec.sped.org [16] CALÁBEK P., ŠVRČEK J., VANĚK V., ZHOUF J. Péče o matematické talenty v České republice, 2010. ISBN 978-80-244-1884-1.

[17] Johns Hopkins Center for Talented Youth. (on-line). Dostupné z: http://cty.jhu.edu.

[18] Př́íklady dobré praxe, (on-line), [cit.

23.1.2013]. Dostupné z:

http://www.msmt.cz/vzdelavani/skolskareforma/ priklady-dobre-praxe

RNDr. Ing. Jana Kalová, Ph.D.

Ústav matematiky a biomatematiky

Př́rodovědecká fakulta JČU

Branišovská 31

37005 České Budějovice, ČR

Tel: +420 387772244

E-mail: jkalova@prf.jcu.cz

Www pracoviště: umb.prf.jcu.cz 